\title{
Formulation of Ointment from Extract Combination of Lemongrass (Cymbopogon nardus L. Rendle), Green Betel Leaf (Piper betle L.) And Natural Zeolite as an Antibacterial Agent
}

\author{
Subur Widodo ${ }^{1}$, Mashuri Yusuf ${ }^{2}$, Laila Susanti $^{3 *}$, Retno Fardila Sari ${ }^{4}$ \\ ${ }^{1234}$ Pharmacy Department, Mathematics and Natural Science Faculty, Tulang Bawang University, \\ Lampung \\ *email: lailasusanti80@gmail.com
}

\section{Article Info}

Key word:

Ointment

Lemongrass

Green betel

Zeolite

Antibacterial

Article history:

Received: 05/08/2020

Revised: $28 / 08 / 2020$

Accepted: 30/08/2020

\begin{abstract}
Lemongrass (Cymbopogon nardus L. Rendle) and green betel (Piper betle L.) plants are native to Indonesia. Empirically betel leaf can be used as a wound healer, lemongrass leaves are widely used as medicine for insect bites. On the basis of information obtained from various literatures, in this research has been done formulation of ointment from extract combination of lemongrass, green betel leaf and natural zeolite as antibacterial of Staphylococcus aureus. The use of zeolites based on features has a three-dimensional framework structure that is interconnected so that it has a large surface. Based on these reasons, it is believed that zeolites can increase the activity of active substances in ointments. The formulation of ointment extracts of lemongrass leaves-green betel leaves and zeolites with various dosages are KZ (zeolite control), KE (20\%-5\%), F1 (10\%-6\% + zeolite), F2 (20\% - 5\% + zeolite), F3 (30\%-4\% + zeolite), F4 $(20 \%-0 \%+$ zeolite), $F 5(0 \%-5 \%+$ zeolite $)$ with a fixed amount of zeolite $(2 \mathrm{gr})$. Evaluation of ointment preparations including organoleptic test, $\mathrm{pH}$, homogeneity, spreading test and adhesion test showed results that met the requirements. The sample was tested for antibacterial activity with positive control (gentamicin $0.1 \%$ ) showed that all formulas can provide an inhibition zone against staphylococcus aureus, except KZ. Test results were analyzed using One Way Annova with sig $(0,000)<p$ value $(0,050)$ followed by Tukey's further tests. From this explanation it can be concluded that the formulation of ointment from extract combination of lemongrass leaves, green betel leaves and zeolites has antibacterial agent.
\end{abstract}

Copyright (C) 2020 Universitas Islam Negeri Raden Fatah Palembang. All Right Reserved

\section{Introduction}

The skin is easily scratched and injured, causing infections caused by a bacterium. The skin is also a part of the body that has a bacterial susceptibility which is commonly found in the skin is Staphylococcus aureus. One of the problems that often occurs in the skin is a skin infection in the wound which is characterized by redness of the skin, swollen pain and the presence of pus in the wound. 
For this problem with the use of topical therapy, the most appropriate dosage form is ointment. Ointments are semi-solid preparations that are easily applied and used as an external drug composed of base compositions and active substances. The basic ingredients commonly used are cera alba and vaselin, whereas for active substances special chemicals are used to treat certain diseases (Arsen, HC., 2008). Prevention of skin infections in wounds and infections in skin diseases can be used antibiotic ointment. However, the long-term use of antibiotic ointments causes side effects such as itching or redness of the skin and can cause added irritation to the skin.

Antibacterial skin ointments are usually made from chemicals that have side effects including only relieving symptoms of the disease, are symptomatic which only reduces suffering, and are palliative. On the basis of some disadvantages of chemical-based drugs, this has begun to be used in the use of herbal ingredients from plants as medicines which are believed to have toxicity and minor side effects. Medicinal plants of various types, habitus, ecology and usefulness, have a great opportunity in contributing to the development of public health, so that people are no longer fully burdened by the increasingly expensive price of chemical drugs. Another advantage of many herbal plants spread throughout the territory of Indonesia so that the selling price of drugs is relatively cheap and affordable for all levels of society.

Various traditional medicines have been used by the community to treat various infectious diseases of the skin caused by bacteria and fungi, including lemongrass leaves (Cymbopogon nardus L. Rendle) and green betel leaves (Piper Betle L.). Lemongrass leaves and green betel leaves are generally found growing wild in the forest, fields or planted in the yard around the house. This plant likes open spaces and sunlight. Traditionally, people use betel as a cough medicine, worm medicine, and wounds. Green betel leaf contains various chemical contents, including essential oils, terpenoids, tannins, polyphenols and steroids which are known as antiseptics. Previous studies of lemongrass leaf extract at a concentration of $20 \%$ had given an inhibition zone of $10.5 \mathrm{~mm}$ response to Propionibacterium acne (Winato BM, dkk.,2019). Another study from Vifta, RL (2017) reported that green betel leaf extract ointment at a concentration of $4 \%$ and $5 \%$ was able to heal wounds due to Staphylococcus aureus infection in rabbits with wound healing time equal to positive control for gentamycin $0.1 \%$. These two plants are considered capable of handling skin problems that are considered disturbing such as infection of the wound. In this research, we want to prove that this research is the best combination of previous studies, by making preparations in the form of ointments and combining active substances in them.

On the basis of information obtained from various literature about the efficacy of these plants, the researchers formulated an ointment formulation of betel leaf extract and lemongrass leaves with a combination of natural zeolites. The choice of zeolite is based on the fact that zeolite has a three-dimensional frame structure with a lot of porosity so that it can act as a catalyst, adsorbent and ion exchange. Zeolite is a natural mineral that has been widely used one of them is as a catalyst that is able to accelerate the rate of chemical reactions without undergoing significant changes as well as zeolites able to maintain stability antibacterial formula extract after heating at high temperatures (Amalia F., 2012).

Several studies have used zeolite as an active ingredient of ointment, namely making ointments based on zeolites which are supported by nitrogen monoxide, then cytotoxic tests on rat animal wounds, the results show that zeolite-NO ointment has no cytotoxic effect and is able to close wounds faster than positive control (Neidrauer, et al., 2014). Another research related to the use of cosmetics is the use of Zn-zeolite as toothpaste, the results show that the quality of $\mathrm{Zn}$-zeolite toothpaste is in accordance with the Chinese national standard. Zn-zeolite toothpaste $5 \%$ can achieve $99.9 \%$ 
antibacterial level against $S$. aureus and $E$. coli, besides that Zn-zeolite toothpaste can reduce the area of color spots on teeth and eliminate bad breath significantly (Difang, Z and Chunsheng X., 2019).

By considering the effect of betel leaf and lemongrass leaf which are efficacious as wound healers and antiseptics that are able to heal wounds and consider the use of natural zeolites based on the physiological structure features that have a three-dimensional framework structure that is interconnected so that it has a broad surface. Based on these reasons, zeolites are believed to be able to act as good adsorbents and catalysts so that they can improve the performance of active substances contained in betel leaf and lemongrass in inhibiting bacterial growth.

Based on the background described above, the specific objectives of this study include making a formulation of ointment combination of citronella leaf extract $(C$. nardus L. Rendle) and green betel leaf ( $P$. betle L.) with a combination of zeolite and knowing the effect of ointment lemongrass leaf extract (C. nardus L. Rendle) and green betel leaf $(P$. betle L.) with zeolite combination as an antibacterial against S.aureus bacteria. This research is also expected to provide benefits, namely getting an ointment formulation that can cure the symptoms of infection caused by S.aureus bacteria so that it can increase the use of traditional medicines in modern dosage forms. It is also expected that this herbal zeolite combination ointment can be an alternative medicine choice instead of chemical drugs.

\section{Materials and Methods}

This study was an experimental laboratory research using Completely Randomized Design (CRD) with 8 treatments groups repetition 3 times with grouping based on the various concentration. The data were collected by measuring the diameter of zone inhibition each treatment group. The data obtained from this study are quantitative data, namely the diameter of the inhibition zone (mm).
Preparation of Extract. Sample of leaves was collected from agricultural land in Bandar Lampung, leaves was dried by being aerated for \pm 3 days and should not be exposed to direct sunlight. Each of 500 grams simplicia was prepared, then dried in an oven at $100^{\circ} \mathrm{C}$, the dry simplicia undergoes the extraction process by means of maceration using 70\% ethanol solvent 5 times, then after maceration the solvent was used with a vacuum distillation device at a temperature of $60^{\circ} \mathrm{C}$ then followed by a hot plate to make the extract mass thick.

Preparation of Zeolit. Natural zeolite used in this study was purchased from CV. Minatama-Bandar Lampung which is 250 mesh in size. This natural zeolite was first heated at $300^{\circ} \mathrm{C}$ for 2 hours to remove the water content and organic impurities trapped in the pores of the zeolite crystals, so that the pore surface area of the zeolite becomes increased.

Formulation of Ointment. The ointments made in this study were of various types of hydrocarbons consist of Lemongrass Extract (LE) and Green Betel Extract (GBE) combination of natural zeolite (Z) as describes in Table 1 below.

Table 1. Formulations of ointment

\begin{tabular}{|c|c|c|c|c|c|}
\hline Formula & $\begin{array}{l}\text { LE } \\
(\%)\end{array}$ & $\begin{array}{c}\text { GBE } \\
(\%)\end{array}$ & $\begin{array}{c}\mathrm{Z} \\
\text { (gr) }\end{array}$ & $\begin{array}{c}\text { Cera } \\
\text { Alba } \\
\text { (gr) }\end{array}$ & $\begin{array}{c}\text { Vaselin } \\
\text { (gr) }\end{array}$ \\
\hline $\mathbf{K Z}$ & 0 & 0 & 2 & 5 & Ad 10 \\
\hline KE & 20 & 5 & 0 & 5 & Ad 10 \\
\hline F1 & 10 & 6 & 2 & 5 & Ad 10 \\
\hline F2 & 20 & 5 & 2 & 5 & Ad 10 \\
\hline F3 & 30 & 4 & 2 & 5 & Ad 10 \\
\hline F4 & 20 & 0 & 2 & 5 & Ad 10 \\
\hline F5 & 0 & 5 & 2 & 5 & Ad 10 \\
\hline $\mathbf{K}+$ & \multicolumn{5}{|c|}{ Gentamicin Ointment $0,1 \%$} \\
\hline
\end{tabular}

\section{Preparation Evaluation of the Ointment}

\section{a. Organoleptic test}

Observe the form, smell and color of the ointment. The ointment specification that must be met is that it has a semi-solid form and does not smell rancid (Voigt, 1995).

\section{b. Homogeneity test}

The ointment sample was applied to a piece of slide. The homogeneous ointment 
was characterized by the absence of lumps on the result of application (Voigt, 1995).

\section{c. Spreadability test}

The ointment sample was placed in the middle of a round glass, covered with another glass and left for 1 minute and then the diameter of the spread was measured. After 1 minute, a load of $50 \mathrm{~g}$ was added and carried out continuously until a sufficient diameter was obtained. The good dispersibility of the ointment is $5-7 \mathrm{~cm}$ (Voigt, 1995).

\section{d. Adhesion test}

The ointment sample was placed on the two glass objects provided, then pressed with a load of $1 \mathrm{~kg}$ for 5 minutes. After that the object glass was attached to the test instrument, the test equipment was given a load of 80 grams and recorded the time of removing the ointment from the slide. The conditions for a good ointment were if the adhesion more than 4 seconds and the longer it takes for the two glass objects to come off, the better the adhesion of the ointment (Voigt, 1995).

Antibacterial Activity Test of Extract Combination Zeolite. An antibacterial power test was performed by preparing sterile Petri dishes containing $20 \mathrm{~mL}$ of Nutrient Agar medium then pouring bacterial S.aureus suspension into a that is in a petri dish that has been cold but not yet solidified, homogenized for 5 minutes and allowed to solidify. Four holes are made on a nutrient agar with a diameter of $5 \mathrm{~mm}$ then each wells hole inserted the test sample using a sterile syringe. Repetition of observations was carried out 3 times. All petri dishes incubated in incubator at $37^{\circ} \mathrm{C}$ at 24 hours.

\section{Results and Discussion}

The extract of lemongrass and green betel leaves was made by maceration using $70 \%$ ethanol as a solvent. The maceration method was chosen because it has its own advantages including the process is quite simple, cheap, easy to do and does not use high temperatures which may damage the chemical compounds contained in the extract (Zhang, QW, et al., 2018).
The choice of ethanol as a solvent is because ethanol solvent is a universal solvent that can attract compounds that are soluble in polar to non-polar solvents. The choice of ethanol with a concentration of $70 \%$ as the solvent is because what is being tested is a dry material, so that $30 \%$ of the water content functions to open the simplicia pores which facilitate the process of withdrawing the compound during extraction. The maserate of lemongrass leaf and green betel leaf were then evaporated using a vacuum distillation device at $60^{\circ} \mathrm{C}$ until $500 \mathrm{~mL}$ of liquid extract were obtained with a blackish brown color. The purpose of evaporation using a vacuum distillation device at $60^{\circ} \mathrm{C}$ is to separate the ethanol solvent from the extract by evaporating the solvent below its boiling point so as to avoid damage to the active substance due to heating. Furthermore, the liquid extract was thickened with a hot plate at $60^{\circ} \mathrm{C}$ with occasional stirring to obtain 103.83 grams of thick extract of lemongrass leaf with a yield of $20,76 \%$ and 70.58 grams of thick extract of green betel leaf with a yield of $14,116 \%$.

Followed by making the ointment preparation carried out by mixing the base of the ointment and the additive in the form of cera alba over a water bath until it melts then transfer it to a warm mortar mixed with zeolit. Zeolite will be dispersed in the fat base and is stable. Then proceed with mixing the extracts of lemongrass and betel leaves then mixed and stirred until everything is even and completely blended. After all the ingredients are mixed, transfer them to the ointment preparation container, let it stand until solid. Evaluation of ointment includes organoleptic tests, homogeneity, spreadability, adhesion, and $\mathrm{pH}$.

Organoleptic test is a visual observation test in the form of shape, color, smell and homogeneity in ointment preparations. Organoleptic observations have been made on the combination ointment preparation of lemongrass leaf extract (C.nardus L. Rendle), green betel leaf (P.Betle L.) and zeolite on day 1 and observed again on day 21 , there was no differences in the ointment preparation 
according to the data that can be seen in Table 2. So it can be said that the ointment is organoleptically stable because it can retain its shape, color, smell and homogeneity for 21 days.

\section{Table 2. Organoleptic Test and Homogeneity of Ointment}

\begin{tabular}{ccccc}
\hline Formul & \multicolumn{3}{c}{ Organoleptics } \\
\cline { 2 - 5 } & Form & Color & Smell & Homogeneity \\
\hline KZ & Semi solid & Greyish White & Typical of vaselin & Homogeneous \\
KE & Semi solid & Brownish Green & Typical of extract & Homogeneous \\
F1 & Semi solid & Dark Green & Typical extract & Homogeneous \\
F2 & Semi solid & Dark Green & Typical of extract & Homogeneous \\
F3 & Semi solid & Blackish Green & Typical of extract & Homogeneous \\
F4 & Semi solid & Brownish & Typical of extract & Homogeneous \\
F5 & Semi solid & Light Green & Typical of extract & Homogeneous \\
\hline
\end{tabular}

The spreadability of the combination ointment for lemongrass leaf extract, green betel leaf and zeolite on day 1 and observed again on day 21 , the results of the evaluation of the quality of the preparation proved that the diameter of the spreadability of the ointment in all formulations was a good spreadability of the ointment, which was between $5-7 \mathrm{~cm}$. There was an increase in the diameter of the ointment preparation after 21 days, but the increase was still within the standard size of the diameter of the ointment preparation. This indicates that the ointment preparation is still good for use because it meets the standard criteria for the diameter size of the spreadability of the ointment which can be seen in Table 3 .

Table 3. Spreadability Test Results

\begin{tabular}{cccc}
\hline Formulation & $\begin{array}{c}\text { Diameter } \\
\text { Spread on } \\
\text { Day-1 } \\
\text { (cm) }\end{array}$ & $\begin{array}{c}\text { Diameter } \\
\text { Spread on } \\
\text { Day -21 } \\
\text { (cm) }\end{array}$ & $\begin{array}{c}\text { Requir } \\
\text { ements }\end{array}$ \\
\hline KZ & 5,10 & 5,40 & \\
KE & 5,50 & 6,00 & \\
F1 & 6,20 & 6,50 & \\
F2 & 5,85 & 6,10 & $5-7 \mathrm{~cm}$ \\
F3 & 5,50 & 5,90 & \\
F4 & 5,30 & 5,50 & \\
F5 & 6,00 & 6,30 &
\end{tabular}

The adhesion evaluation test has been carried out, the results of the evaluation test proved that the length of time for the adhesion of the ointment preparation to all formulations was a good adhesion of the ointment for use, which was between 3-4 seconds or more than 4 seconds. The longer the ointment is able to adhere to the slide, the better the adhesion of the ointment. There was a decrease in the length of the ointment preparation after day 21 , but the decrease was still within the standard of spreadability of the ointment preparation which was said to be good. This indicates that the ointment preparation is still good for use because it meets the standard criteria for the adhesion of the ointment preparation which can be seen in Table 4 .

Table 4. Adhesion Power Test Results

\begin{tabular}{cccc}
\hline Formulation & $\begin{array}{l}\text { Day-1 } \\
\text { (second) }\end{array}$ & $\begin{array}{l}\text { Day-21 } \\
\text { (second) }\end{array}$ & Requirements \\
\hline KZ & 4,70 & 4,45 & \\
KE & 3,78 & 3,50 & \\
F1 & 3,88 & 3,54 & \\
F2 & 4,21 & 3,87 & $>4$ second \\
F3 & 3,76 & 3,48 & \\
F4 & 3,95 & 3,62 & \\
F5 & 4,92 & 4,65 & \\
\hline
\end{tabular}

The $\mathrm{pH}$ test of the ointment was carried out using a $\mathrm{pH}$ meter. The $\mathrm{pH}$ meter is immersed in a preparation that has been dissolved with distilled water, then seen until the number is constant. The $\mathrm{pH}$ of each preparation with various formulations will be measured the $\mathrm{pH}$. The $\mathrm{pH}$ requirement for topical preparations is 4.5-6.5 because normal skin $\mathrm{pH}$ has this $\mathrm{pH}$ range (Anief, 2006). The $\mathrm{pH}$ test or the degree of acidity has been tested on the combination of lemongrass leaf extract, green betel leaf and zeolite ointment preparation on day 1 and observed again on day 21 and describes on Table 5 below, the results of the acidity level test prove that the $\mathrm{pH}$ size of the ointment in all formulations is a good degree of acidity, which is between $\mathrm{pH}$ 
4,5-6,5 according to the set standard to be used on the skin. There were various changes in the degree of acidity after the 21 st day, but the increase or decrease in the degree of acidity was still within the standard measure of the degree of acidity in the ointment preparation. This indicates that the ointment preparation is still good for use because it meets the standard criteria for the degree of acidity of the ointment preparation.

Table 5. pH Test Results

\begin{tabular}{lrrr}
\hline Formulation & $\begin{array}{l}\text { Day-1 } \\
(\mathbf{p H})\end{array}$ & $\begin{array}{l}\text { Day-21 } \\
\mathbf{( p H )}\end{array}$ & Requirements \\
\hline KZ & 5,5 & 5,4 & \\
KE & 5,0 & 5,3 & \\
F1 & 5,2 & 4,9 & $4,5-6,5$ \\
F2 & 5,2 & 5,0 & \\
F3 & 4,8 & 5,1 & \\
F4 & 5,1 & 5,6 & \\
F5 & 5,3 & 5,5 & \\
\hline
\end{tabular}

The results of the antibacterial activity test of all formulas against $S$. aureus bacteria after three repetititon and the classification of inhibition of bacterial growth follows Greenwood (1995) are presented on Table 6 and 7 below.

Table 6. Classification of inhibition of bacterial growth (Greenwood 1995).

\begin{tabular}{cc}
\hline $\begin{array}{l}\text { Inhibition Zone } \\
\text { Diameter }(\mathbf{m m})\end{array}$ & Inhibition Response \\
\hline$>20$ & Strong \\
$16-20$ & Medium \\
$10-15$ & Weak \\
$<10$ & None \\
\hline
\end{tabular}

Table 7. Result of Inhibition Zone Diameter of Ointment

\begin{tabular}{ccc}
\hline Formulasi & $\begin{array}{l}\text { Average } \\
\text { Diameter }(\mathbf{m m})\end{array}$ & $\begin{array}{l}\text { Inhibition } \\
\text { Response }\end{array}$ \\
\hline KZ & $0,00 \pm 0,00^{\mathrm{a}}$ & None \\
K+ & $20,68 \pm 0.05^{\mathrm{b}}$ & Strong \\
KE & $15,51 \pm 0.07^{\mathrm{c}}$ & Weak \\
F1 & $22,30 \pm 0,06^{\mathrm{d}}$ & Strong \\
F2 & $24,36 \pm 0,05^{\mathrm{e}}$ & Strong \\
F3 & $25,33 \pm 0,08^{\mathrm{e}}$ & Strong \\
F4 & $20,96 \pm 0,07^{\mathrm{b}}$ & Strong \\
F5 & $22,20 \pm 0,08^{\mathrm{d}}$ & Strong
\end{tabular}

Note: The numbers in the same column are followed tika over the same letter (after the deviation standard) was not significantly different at the $5 \%$ test level (Tukey Test).

The results of the inhibition zone in the petri dishes of all formulas are presented in Figure 1 below.
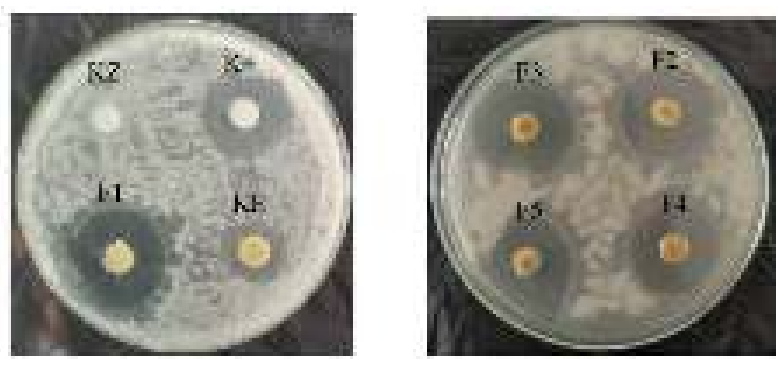

\section{Picture 1. Inhibition zone results for all} formulas

Based on Table 7 and Figure 1, the results showed that all formulas can inhibit $S$. aureus except KZ. This shows that the ointment containing only zeolite is unable to inhibit bacteria because there are no active compounds from plant extracts in the $\mathrm{KZ}$ formula. This is the background behind the presence of active substances from the extract plants that serve as antibacterial include flavonoids, alkaloids, tannins. Antibacterial ability of green betel leaves influenced by the content of metabolite compounds secondary flavonoids, saponins, and tannins. Flavonoids can act as antibacterial through the mechanism of destroying the cell membrane (Bhalodia and Shukla, 2011). Mechanism antibacterial on flavonoids affect the process enzymatic bacteria by means of inactivating enzymes in microbial cells (Darmawi, dkk., 2013).

The active compound contained in plant extracts has inhibitory mechanism in a way interfere with constituent components peptidoglycan on bacterial cells, so the cell wall layer is not formed intact and causes cell death. Another mechanism is that it occurs denaturation of protein thereby increasing cell membrane permeability. Denaturation protein causes disturbances in

cell formation thus transforming protein component composition, function disturbed cell membranes can cause to increase cell permeability, so that resulting in damage to bacterial cells (Susanti, L, dkk., 2018). 
However, an interesting thing happens when zeolite is combined with plant extracts, resulting in an inhibition zone that exceeds positive control $(\mathrm{K}+)$ and Extract Control (KE). This shows the existence of zeolite capable to improve the performance of plants extracts in inhibiting bacteria, because as is well known zeolite framework structure has pores which act as adsorbent capable to binds the active compounds from plant extracts and releases the active compounds again as ion exchangers (Ginting, dkk., 2007; Arif, dkk., 2011; Subariyah, dkk., 2013).

Some literature shows zeolite can increase antibacterial activity such as $\mathrm{Cu}$ zeolite metal can inhibit antibacterial activity of $S$. aureus, $S$. mutans, A. baumannii (Sunarintyas, dkk., 2016). Other studies reported that ointment zeolite-NO which was carried out by cytotoxic test on the wounds of rat test animals, resulted that zeolite-NO ointment does not cause a cytotoxic effect and is able closes the wound faster than ever with positive control (Neidrauer, et al., 2014)

The results of statistical tests using One Way Annova with a sigma value $(0.000)$ $<\mathrm{p}$ value $(0.050)$ followed by Tukey's further test indicates that there is a significant difference between $\mathrm{KZ}$ and KE, F1, F2, F3, F4 dan F5. However, the F1, F2, F3, F4 and F5 formulas do not show a significant difference.

\section{Conclusion}

The presence of zeolite can improve the performance of ointment from extract combination of lemongrass leaves, green betel leaves, especially at formula F2 and F3 with a strong inhibition zone response beyond gentamycin $(\mathrm{K}+)$ and extract control without zeolite (KE) in inhibiting Staphylococcus aureus. From this explanation, it can be concluded that ointment from extract combination of lemongrass leaves, green betel leaves and zeolite can be used as an alternative medicine substitute chemical synthetic drugs as antibacterial agent.

\section{References}

Anief M.,(2006). Farmasetika, Gadjah Mada University Press, Yogyakarta.
Ansel, H.C. (2008). Penghantar Bentuk Sediaan Farmasi, Edisi keempat. Jakarta: Universitas Indonesia Press.

Arif, Z. (2011). Karakterisasi dan Modifikasi Zeolit Alam sebagai Bahan Media Pendeteksi Studi Kasus: Kromium Heksavalen. Fakultas Matematika dan Ilmu Pengetahuan, Institut Pertanian Bogor.

Bhalodia, N.R., Shukla, V.J., (2011). Antibacterial and Antifungal Activities From Leaf Extracts of Casia fistula I. : An ethonomedical Plant. $J$. Adv. Pharm Technol Res. 2(2), 104109.

Bhatia, VN and Barber RH. (1955). The Effect of $\mathrm{pH}$ Variations of Ointment Bases on The Local Anesthetic Activity of Incorporated Ethyl Aminobenzoate *I. Hydrophilic Ointment U.S.P. Journal of The American Pharmaceutical Association (scientific ed.). 44(6), 342-343.

Cooper GM., Hausman RE. (2007). The

Cell : A Molecular Approach . 4th ed. Sunderland : Sinauer Associates, Inc.

Darmawi, Zakiyah H.M., Fahri P. (2013). Daya Hambat Getah Jarak Cina (Jatropha multifida L.) terhadap Staphylococcus aureus Secara In Vitro. Jurnal Medika Veterinaria. 7,113-115.

Difang, Z dan Chunsheng, X. (2019): Study on the Application of Zinc-zeolite in Cosmetic Toothpaste. American Journal of Chemical Engineering, 7(2): 65-70, doi: 10.11648/j.ajche.20190702.12

Fitri Amalia. (2012). Formulasi Ekstrak Kulit Buah Delima dan Daun Dewandaru Sebagai Antibakteri dan Penggunaan Zeolit untuk Menjaga Stabilitas Formula. (Tesis). Bogor. Insitut Pertanian Bogor.

Amalia F, Purwamargapratala Y. (2017).

Penggunaan Zeolit Untuk Stabilisasi Formula Ekstrak Kulit Buah Delima Sebagai Antibakteri. Jurnal Kimia dan Kemasan. 39(1), 25-30. 
Ginting A.B., D. Anggraini, S. Indaryati, dan R. Kriswarini. (2007). Karakterisasi Komposisi Kimia, Luas Permukaan Pori dan Sifat Termal dari Zeolit Bayah, Tasikmalaya, dan Lam-pung. Jurnal Teknik Bahan Nuklir. 3(1):148.

Greenwood D. (1995). Antibiotics

Susceptibility (Sensitivity) Test, Antimicrobial and Chemotheraphy. United State of America: Mc Graw Hill Company.

Subariyah, I., A. Zakaria, dan Y. Purwamargapratala. (2013). Karakterisasi Zeolit Alam Lampung Teraktivasi Asam Klorida dan Termodifikasi Asam Fosfat. Jurnal Teknologi Pengelolaan Limbah. 16 (3) ; 17-24.

Sunarintyas S, Widyastuti NH, Iman $\mathrm{CW}$. (2006). Pengaruh Aktivasi Panas dan Penambahan $\mathrm{Cu}$ pada Zeolit Terhadap Daya Antimikroba Pada Staphylococcus aureus. Indonesian Journal of Dentistry. Edisi Khusus KPPIKG XIV.

Susanti, L., Wahidah, LK., Viogenta, P.

(2018). Optimasi Zeolit Alam Lampung (ZAL) Sebagai Penstabil Sediaan Antibakteri Esktrak Buah Mengkudu (Morinda citrifolia L). Jurnal Farmasi Lampung (JFL), 7(2);60-67.

Susanti, L ., Wahidah, LK., Viogenta,

P. (2020). Formulasi Salep Ekstrak Buah Mengkudu (Morinda citrifolia L.) Kombinasi Zeolit Alam Lampung (ZAL) Sebagai Penstabil Sediaan Antibakteri Staphylococcus aureus. Jurnal Pharmascience. (7)1; 9-17.

Neidrauer, M., Ecan U.K., Battharyya

A.,Samuels J., Sediak J.,Trikha R. (2014). Antimicrobial Efficacy and Wound Healing Property of Topical Ointment Containing Nitric-Oxide Loaded Zeolites. Journal of Medical Microbiology. 63(pt.2):203-209.

Voigt. (1995). Teknologi Farmasi Edisi V.

Yogyakarta: Gadjah Mada University Press;. 564, 3337, 382, 312 p. 1995.
Vifta RL., Wansyah PMA., Hati AK. (2017). Aktivitas antibakteri salep ekstrak etanol daun sirih hijau (Piper betle L.) Terhadap infeksi bakteri Staphylococcus aureus. Kartika Jurnal Ilmiah Farmasi, 5(2), 56-61.

Winato, BM., Sanjaya E., Siregar L., Fau SKYMV., Mutia MS. (2019). Antibacterial Activity Of Serai Wangi Leaf Extract (Cymbopogon Nardus) Against Propionibacterium Acnes. BioLink Jurnal Biologi Lingkungan, Industri, Kesehatan. 6(1),50-58.

Zhang, QW., Lin, LG., Ye, WC (2018).

Techniques for Extraction and Isolation of Natural Products: a Comprehensive Review. Chinese Medicine, (13) 20, 1-55. 